\title{
Types of Multiple Intelligence Common Among College of Education Students at Dammam University and Their Relation with Specialization, Scholastic Year and Grade Point Average(GPA)
}

\author{
Dr. Ra'eda Mohammad Rasheed \\ Assistant Professor in Curricula Philosophy and Mathematics Methodology \\ University of Dammam- College of Education- \\ Education \& Psychology Department
}

doi: 10.19044/esj.2016.v12n31p128 URL:http://dx.doi.org/10.19044/esj.2016.v12n31p128

\begin{abstract}
This study aimed to identify the kinds of multiple intelligence common among the College of Education students at Dammam University. The study sample consisted of (201) students specialized in Mathematics, Physics ,Computer Science, English and Kindergarten and the preparatory year of scientific and literary streams. Mackenzie Inventory for Multiple Intelligence (Mackenzie, 1999) was used, after confirming its validity and reliability. The study results indicated an acceptable ratio of multiple intelligence communality among the students of the College of Education at Jubail/University of Dammam regarding the communality of multiple intelligence among them. The most common kind of intelligence was intrapersonal intelligence, while the least common was musical intelligence. The communality level ratio of mathematical-logical intelligence, visual intelligence, linguistic intelligence, interpersonal intelligence (social) and bodily- kinesthetic intelligence were approximate. There was a significant difference attributed to interaction among students' multiple intelligence, specialization, scholastic year and Grade Point Average (GPA).
\end{abstract}

Keywords: Multiple Intelligence, College of Education Students, Dammam University, (GPA)

\section{Introduction}

Educational system in the twentieth century, and in many countries all over the world, was distinguished by quality education. The concern was focused on developing learners' potentials and intellectual abilities, as much as possible, after proving the importance of the human wealth in societal development and progress, since it is the most important source of 
development. At the beginning of the $3^{\text {rd }}$ millennium, the educational system carried on focusing on developing and nurturing learners' minds, so as to fulfill their community's ambitions, and play a decisive role in the postindustry community. This requires learners to have a high degree of cognitive adaptation. Therefore, efforts have been focused on effective educational planning to develop and build school syllabuses, based on the outcomes of the scientific data of the contemporary psychological studies, especially in the field of cognitive psychology. Hence, research is keen on developing school syllabuses through analyzing and investigating learning mechanisms. This led to the emergence of numerous educational theories that tried to interpret the differences in individuals' learning abilities and to design learning styles based on such differences. The most important among such theories was Multiple Intelligence Theory, which was based on cognitive science, representing efforts made to reconsider the measurable intelligence theory included in intelligence tests (Silver, Strong \& Perini, 1997). This is a relatively old theory, since it was put forward by Howard Gardner in 1983. Since then, this theory has exceeded its theoretical range to practical application, with researchers from various fields working on it to gain the greatest benefit from applying it on child development at both families and schools. Gardner contradicted the unilateral conception of human intelligence, when he announced that each of us has at least one, or more of eight kinds of intelligence that vary in their proportion, and interact in a complicated way making any individual unique in his/her intelligence. Gardner defines intelligence as the ability of solving problems, or adding a new valuable outcome in one or more of the cultural frameworks (Gardner, 1993). This definition emphasizes the term (problem solving). Intelligence, according to Gardner, is important in developing individuals' intellectual abilities that include the skill of problem -solving. This facilitates acquiring new knowledge, which is stored in long-term memory in the form of cognitive structuring that are recalled when they encounter a mysterious situation that hinders their understanding, and so, they employ such skills and experience in solving all kinds of problems they may be encountered, including mathematical problems. This definition also emphasizes the terminology of (ability) indicating individual has the competence that qualifies their performance. In building his theory, Gardner benefited from brain research, and assured having signs indicating that some of the brain zones respond to definite kinds of knowledge. These zones include synapses organized in a way that supports the ideas of multiple patterns of processing information and the variance of abilities or intellectual competencies that an individual may possess (Gardner, 1983). According to Gardner, intelligence is a biological energy latent in neurons, and can be activated through appropriate environmental stimuli. This leads to increasing individual's 
competence and ability because of the experience gained from the process of teaching and learning represented by dealing with different kinds of environments. Gardner's theory is useful in knowing teaching and learning styles. This theory detects points of weakness and strength among learners. According to the theory of multiple intelligence, each individual possesses, at least, various degrees of eight kinds of intelligence that work together in an integral way, and are influenced by, and influence individuals' way of learning. Therefore, the way individuals learn reflects the kinds of intelligence they have (Jaber, 2003).The educational practices before the emergence of multiple intelligence theory used to focus on one learning style, because educators believed that there is only one kind of intelligence. This made the majority of learners miss the opportunities of effective learning according to their own learning style. IQ Factor theory takes just some of the learners' abilities into consideration, such as the linguistic, logical and mathematical abilities. This led teachers to ignore many other abilities greatly valued by societies. Meanwhile, multiple intelligence revolutionized quality movement in our view of intelligence. It indicated that having multiple and different kinds of intelligence among learners requires following various educational inlets to achieve communication with all learners available in the classroom. Modern educational applications emphasize that multiple intelligence theory is effective in various aspects. This includes: improving students' achievement levels, raising their interest towards the learning content and the ability of using multiple intelligence as an entrance to teach using multiple methods (Afanah \& Khazandar, 2007). This theory also inducted educators to understand students' abilities and interests, to use fair measurement tools that focus on abilities, match society needs with such interests, and the flexibility and freedom of teaching students such as students' choice of the method that fits their study (Sorour,1998).

\section{Study Problem}

The problem of the current study lies in its attempt to contribute in helping students to express the kind of multiple intelligence they have through their learning styles. These methods indicate the kind of intelligence they have, if their teachers provide them with the opportunity to choose the methods that fit their study. As for teachers, they are considered the most important chain in the teaching process. They are capable and competent of understanding their students' abilities and interests, and dealing with their as learners. In addition, they focus on selecting the evaluation tools that fit the style they follow in learning, according to their multiple intelligence. Colleges of Education should focus on teaching the important vocational topics that help in preparing female teacher-students professionally exactly 
as being prepared academically. Multiple intelligence is considered one of the important topics that the College of Education graduates should be exposed to.

\section{Study Questions}

The current study aims to answer the following main question:

((What are the kinds of Multiple Intelligence Common among College of Education Students at Dammam University and what are their relationships with specialization, scholastic year and Grade Point Average (GPA)?)). Five minor questions emerged from this main question:

1. What are the kinds of Multiple Intelligence Common among College of Education students at Dammam University?

2. Is there a difference in the kinds of multiple intelligence common among the College of Education students at Dammam University that is ascribed to university specialization?

3. Is there a difference in the kinds of multiple intelligence common among the College of Education students at Dammam University that is ascribed to scholastic year?

4. Is there a difference in the kinds of multiple intelligence common among the College of Education students at Dammam University that is ascribed to interaction between the university specialization and scholastic year?

5. Is there a correlative relationship between the kinds of multiple intelligence common among the College of Education students at Dammam University and Grade Point Average(GPA)?

\section{Procedural Definitions of Concepts and Terminology:}

- $\quad$ Kind of multiple intelligence: one of the following seven kinds of intelligence (according to Gardener's classification): Verbal or linguistic, logical or mathematical, spatial, bodily-kinesthetic, interpersonal, intrapersonal, musical).

- Students of College of Education at Jubail: The students of the preparatory year are in its two branches: scientific branch and literary branch. Students of $1^{\text {st }}$ year, $2^{\text {nd }}$ year, $3^{\text {rd }}$ year and $4^{\text {th }}$ year specialize in Kindergarten, Physics, Mathematics, Computer, and English at the College of Education at Jubail/University of Dammam at the Eastern District of Saudi Arabia for the scholastic year 1434h/1435h.

- University of Dammam: a State University at the Eastern Area of Saudi Arabia.

- $\quad$ Specialization: The specializations of the study- sample subjects at the College of Education, Jubail which are teachers of: Mathematics, Computer Science, Physics, Kindergarten, and English, and the students of 
general preparation (preparatory year in its two branches: scientific branch and literary branch before joining the above-mentioned specializations).

- $\quad$ Scholastic year: $1^{\text {st }}$ year, $2^{\text {nd }}$ year, $3^{\text {rd }}$ year and $4^{\text {th }}$ for the scholastic year 1434h/1435h.

- Grade Point Average (GPA): Student's average during the scholastic semesters that they had studied according to the university plan that prepares them academically (specialization courses) and professionally (Curricula and Methodology, and Psychology courses).

\section{Study Limitations}

The results of the current study shall be considered within the following limitations:

- $\quad$ Sample: The study sample includes a sample of the preparatory year in its two branches: scientific branch and literary branch, $1^{\text {st }}$ year, $2^{\text {nd }}$ year, $3^{\text {rd }}$ year and $4^{\text {th }}$ four students specialized in kindergarten, Physics, Mathematics, Computer, and English at the College of Education at Jubail/University of Dammam at the Eastern District of Saudi Arabia for the scholastic year 1434h/1435h.

- $\quad$ Research Tools: The study shall be limited by the validity and reliability of the measures applied in this study which are: Mackenzie Multiple Intelligence Inventory (Mackenzie, 1999), which was translated into Arabic, and the content validity significance was produced through reviewers. The study adopted 70 paragraphs of the original scale paragraphs which represent musical intelligence, mathematical - logical intelligence, interpersonal (social) intelligence, bodily-kinesthetic intelligence, linguistic intelligence, intrapersonal intelligence and visual intelligence.

- Intelligence Kind: Knowing the kinds of intelligence common among College of Education students at Dammam University and their relation to specialization, scholastic Year and Grade Point Average (GPA).

- $\quad$ Scholastic Year: Students at $\left(1^{\text {st }}\right.$ year, $2^{\text {nd }}$ year, $3^{\text {rd }}$ year and $4^{\text {th }}$ year $)$ for the university scholastic year 1434h/1435h.

- Grade Point Average(GPA): University cumulative average that the study subject obtained until the scholastic year in which the research was applied during the scholastic semesters that she had studied according to the university plan that prepares them academically ( specialization courses) and professionally( Curricula and Methodology courses and Psychology courses).

\section{Study Importance}

We can say that the employment of multiple intelligence for the purpose of improving students' learning is a relatively new trend in teaching, 
in general, and university teaching in particular. Educators have just recently recognized and discovered multiple intelligence. This can be seen in the rarity of studies concerning such topic. Traditional Universities used to and still focus on linguistic and logical methodologies, in addition to a limited number of teaching and learning styles. Most universities depend on direct instruction, readings, research and practical experiments, if available, in addition to making many exams in order to deepen and review learning. As a result, students who prefer this learning style are described as intelligent, while students who prefer different learning styles are described as being less intelligent and so less able to solve problems, which leads to reducing their motivation to learn. However, if students' multiple and common kinds of intelligence are recognized and discovered, it is possible that teachers employ teaching strategies that are more appropriate to such variety. This improves learning quality and speed, fosters students" ability to solve problems and increases their motivation. For all these reasons, the current study aims to investigate the multiple kinds of intelligence common among university students. On the other hand, students selected for this study are at the College of Education, a college that graduates teachers to adopt teaching as a career. If they were taught according to the kinds of multiple intelligence common among them, they would follow the steps of those who taught them to adopt such approach. In addition to the necessity of the Faculty of Education focusing on teaching the important professional topics that help in the professionally preparing students in the same way they are prepared academically. Multiple intelligence is considered one of the important topics that the students and graduates of the College of Education should acquire , furthermore, the College of Education graduates should be armed with some important scientific topics such as multiple intelligence and the learning styles preferred by learners. From all that has been mentioned, theoretically, it is hoped that the theoretical results of this study may shed light on the necessity of employing multiple intelligence at university teaching and learning. Thus, we hope that the educational system may achieve a lot, if they pay attention to the mental abilities that the scales of the IQ do not consider. This can be carried out by varying the teaching techniques that care about students' learning styles and preferences, concentrating on novelty and originality, while applying such strategies on learners and understanding their nature and the variability of their intelligence and the different learning styles. In practice, it is hoped that the results of this and other studies play their roles in improving the teaching outcomes, since they guide educational decision makers to benefit from the strategy of multiple intelligence in developing and evaluating the syllabuses of university education, and in designing the plan of teachers' training before service and in service. 


\section{Theoretical Frame and Previous Studies:}

\section{Theoretical Framework: Multiple Intelligence Theory}

The concept of human intelligence has received a great amount of Psychologists' care all through the past decades, but so far, there is no singular definition of intelligence that may satisfy all psychologists. There is a consensus on the kinds of mental activity and knowledge that are considered human intelligence. Intelligence is an indefinite concept that includes perception, learning, recall, inference and problem solving (Jaber, 1997). There were various studies and theories that tried to introduce practical interpretations in a systematic or logical way. . These studies were graded from one factor, two factors and multi-dimensional components of intelligence. The traditional view of intelligence revolves around two contradictory poles: first, mono- perspective, which states that individuals' mental ability is a unified unity built on the substitution and linguistic abilities. It is an innate ability, and that the effect of education on it is limited. It can be measured by using standardized IQ tests. The traditional concept of intelligence is linked to the concept (intelligence quotient- IQ) which measures the examinees' mental performance, based on a standard test developed for the first time by the French Researchers Binet \& Stanford (1916) based on the Uni-factor Theory that was established by Alfred Binet. The other pole is based on the idea of dynamic and multiple intelligence that is adopted by cognitive psychologists, who propose that intelligence mostly includes many different formations of thinking. The most important theory is the two-factor theory, which was published by Spearman in 1927, and Thorndike theory (1927), the primary mental ability by Thurston (1938), Piaget for cognitive development (1952), Cattell (1958), Guilford Model of mind formation which he developed in 1959 and 1989.Currently. it is no longer acceptable that one intelligence factor represents the total mental, intellectual capacity, because changing intelligence into numbers of one form is misleading since the mental growth is dynamic with multi-faceted. Moreover, the exclusive use of intelligence as an indicator of mental ability reduces the value of the great potentials in all people. In addition, such degrees fail in predicting the success or failure of any individual in both academic and non-academic environments (Afaneh \& Khazandar, 2007).Thus, Howard Gardener began to focus on the psychology of macro learning to conclude his theory of multiple intelligence at the time formal education focused basically on logical, mathematical, linguistic and verbal skills. Many educators believe that, although many years have passed since Gardener's publication of his well-known book "Frame of Mind: Multiple Intelligence", in 1983. The clear and comprehensive design set by Gardner still confuses the educational society: "Who could expect that the redefinition of 'intelligence' would deeply influence the way we look at 
ourselves and our students?” (Silver, Strong \& Perni, 1997). Gardner defined intelligence as "a potential bio-psychological ability to process information with the purpose of solving problems, or creating outputs related to a certain cultural frame." Gardner explains that problem - solving skills enable individuals to approximate situations at which a certain goal is set, along with deciding a certain approach to follow in order to achieve that aim. Meanwhile, creativity of cultural output is considered a decisive factor in storing and transferring knowledge, and in individuals' expression of their ideas or feelings (Gardener, 1993, 1999).This definition also suggests that intelligence is not a visible or credible thing. It is a neurological potential, or a potential biological capacity in the neurological cell that may be activated or not, based on certain cultural values, opportunities available at such culture and the personal decisions taken by the individuals and their families, teachers and others (Afaneh \& Khazandar,2007). Thus, intelligence in this theory does not consist of just one factor, but from multiple dimensions. Each individual is distinguished from the other by the kind of intelligence they prefer to employ. In this way, Gardner has extended intelligence as a terminology to conclude the maximum capacities used to be considered outside the range of intelligence. He considered the human intelligence as relatively independent faculties. Therefore, we cannot consider any individual as intelligent or stupid, based on whether or not they possess one mental ability (Gardener, 1999). In 1993, Gardener added another kind of intelligence called "natural intelligence". These eight kinds of intelligence can be summarized as follows (Gardner,2005;Hussein, 2005; Afaneh \& Khazandar,2007): First, linguistic verbal intelligence: the ability to use language, sensitivity towards words and their meaning, knowing grammatical rules, the ability to know eloquence, poetry writing and reading, writing and reading short stories and speeches, and the ability to clearly transfer concepts. People with linguistic intelligence enjoy reading and rambling at libraries. The most prominent examples of linguistic intelligent people are poets, orators and announcers. Second, logical- mathematical intelligence: represented by the individual's mathematical and logical ability on abstract thinking and problem solving. This ability includes individual's ability to listen to and organize facts, use the skills of logical inference, the use of abstract symbols and equations, solving mentally difficult problems, data analysis, use of graphical charts and figures, work by using number series, use of computers and calculators, use of coding and decoding, analysis of powers, relations and various scales, creating new patterns, setting hypotheses and making use of experiments and research results. The mathematically intelligent people are represented by mathematics scientists, engineers, physicians, researchers, accountants and computer programmers. Third, Intrapersonal Intelligence: this indicates the individual's ability to 
form a clear and accurate pattern by him/herself, and to actively use such pattern fundamentally in their life, realizing the feelings of joy and pain. Such individuals like to depend on themselves. They also have a motivation to work alone, and to enjoy their life and time in an influential and effective way through self-reflection. They are characterized by fortitude, challenge and self-confidence. They are inclined to stick to religious and morals values. These are the qualities of philosophers, scientists and wise men. Fourth, Interpersonal Intelligence: this indicates strong notification, the ability to distinguish differences among people, especially with regard to their intelligence, temper and features and knowing their intentions and desires. Such people are characterized by the ability to build social relationships, communicating with others, and strong observation. These are the qualities of religious men, politicians enjoying insight and broad knowledge, educators, psychological advisors and sales clerks. Fifth, Musical Intelligence: this includes the ability to distinguish sounds and rhythms, composing music and listening to it, exactly as singers, composers, players and sound engineers. Such people enjoy singing and composing musical notes. Sixth, Visual/Spatial Intelligence: this indicates individuals' broad realization of the world around them, the ability to visualize and know directions, and estimate distances and volumes. Such Individuals like to process things in their mind, have clear dreams during their sleep, and can remember and interpret them. They also like art and practice drawing, planning and photography. Examples of such intelligent people are engineers, painters, décor engineers, architects and sailors. Seventh, BodilyKinesthetic intelligence: this indicates individual's ability to control their body motions, such as swimmers, clowns, actors, dancers, artisans and surgical doctors. Such individuals like movement, playing sports, walking, wandering, enjoy jogging and running, mimicking and acting, move their hands and feet while talking. Eighth, Naturalist Intelligence: this indicates the individual's ability to understand nature with its animals and plants and their ability to classify living creatures and non-living things. Such people enjoy raising pets, garden-landscape, orientation at forests and natural places, and investigating problems and issues of ecology and how to solve such problems. Examples of such people are farmers, hunters, botanists and zoologists, geologists and archeologists. The criteria used by Gardner include the following developmental criteria :The possibility of isolating intelligence as a result of brain damage, having abnormal children, distinguished developmental history, a group of clearly defined experience of performances, evolutionary history, support of experimental psychological tasks, ability of coding in a code-system, an axial process that can be distinguished and defined, or a group of operations and procedures, in addition to psychometric results (Jaber, 2003).Up to now, intelligence is still 
open to adding other types of intelligence that show the vastness and greatness of human abilities and potentials that have not been searched before, in the form adopted by Gardner. Gardner considered this intuitive knowledge with human experience to show us that they are correct by using research characterized by validity, clarity, and the ability to convince (Silver, Strong \& Perini, 1997).Nevertheless, multiple intelligence theory has two gaps that limit their application to learning. The first gap is that the theory stemmed from the cognitive theory, which is a cognitive branch and he has not asked himself why we have a cognitive area called cognitive science. But not Affective Science. On the other hand, the roots of learning styles go further into psychoanalysis, and so, learning style theories give a central role to psychological effect and personality in understanding differences in learning. In addition, the theory sheds light on what the learning styles theory can uncover, since multiple intelligence theory focuses on the learning content and its relation with cognitive areas. Such focus means that multiple intelligence theory does not care about individual processes of learning. This is the second gap of the theory which becomes more obvious if we take into consideration the differences within one intelligence (Silver, Strong \&Perini, 1997). Thus, multiple intelligence theory can be applied flexibly using different kinds of styles that allow certain students or certain teachers or certain syllabuses (Willis \& Jhonson,2001 as provided in Afanah \& Khazandar,2007).According to multiple intelligence theory, learning and teaching materials and activities employed in teaching mathematics can be varied depending on the targeted intelligence. For the purpose of fostering the learning of students who are intelligent in language, students' textbooks, audio cassettes, worksheets and diaries, can be employed, in addition to focusing on the learning activities that include reading speech letters, writing mathematical stories, listening to explanation and speaking about strategies. Meanwhile, learning activities focus on telling stories, providing book corners, telling jokes and having fun, questions and evaluation tasks, lectures, and written or oral explanation. Logically intelligent students make better use of some materials, such as calculators and games, number lines, charts and artistic figures. Learning activities can be employed using paraphrasing or solving difficult mental problems, logical problems and puzzles, equations and algorithm, in addition to thinking and interpretation. Meanwhile, learning activities focus on linking with previous concepts, variation of representations, exploratory methods. Spatial intelligent students had better employ computers, charts, maps, playing cards, dominos, teaching aids and bulletin boards. Charts drawing activities may include forming other pictures or representations and watching illustrative drawings. While learning activities may focus on mind patterns, visual instructions and hints such as colors, circles, boxes and arrows. Learning can be achieved through 
using guided learning, graphic organizers, and conceptual maps. To foster the learning of musically intelligent students, sound recording devices, CDs and musical instruments can be used. Meanwhile, learning activities may deal with composing, performing, or listening to songs or hymns, using musical notes and forming rhythmic patterns. Based on what has been previously mentioned, this study aimed to benefit from the ideas concerned with the diversification of teaching and learning activities in a way that is appropriate with multiple intelligence. This can be used in building a teaching program for one of the mathematical content topics, with the aim of fostering students' abilities to achieve the aims of learning mathematics, and most importantly, the ability to solve problems, and to improve their motivation to learn mathematics.

\section{Previous studies of Multiple Intelligence}

Ahmadyan (2013), carried out a study that aimed to identify the influence of teaching strategies that depend on multiple intelligence on their achievement in Science. The study used the experimental approach for a sample consisting of 40 subjects: 20 subjects as a control group, and 20 subject as experimental group. The study concluded that there is a rise in science achievement among the experimental group subjects that were taught with strategies depending on multiple intelligence, compared with the control group subjects who were taught using the usual method. Zaytoun(2010), carried out a study that aimed to investigate the influence of teaching a program based on merging multiple intelligence and learning styles on the UNRWA $8^{\text {th }}$ grade students' abilities of solving mathematical problems, and their motivation towards learning mathematics. The study used the quasi-experimental approach through pre and post application of the study instruments. The sample was intentionally selected and randomly divided into two groups: Class (a) with 39subjects, as an experimental group class; (b) with37) subjects as control group. Thus, the total sample consisted of 76 subjects. The study instrument was a teaching program which also measured students' ability to solve mathematical problems, in addition to using the self-motivation scale. The study concluded that there is a positive effect on the teaching program demonstrated by students' ability to solve mathematical problems. There were also significant differences in the means of the $8^{\text {th }}$ grade students raw marks in both experimental and control groups, for the benefit of the post application on the three dimensions of the selfmotivation scale (perseverance, ambition, having an aim to be achieved).There was no difference in the development of perseverance, ambition and self-motivation towards learning mathematics that can be ascribed to the teaching program. There was a difference in developing an aim they seek to achieve among the $8^{\text {th }}$ grade students that can be ascribed to 
the teaching program. Christison \& Kennedy (1999) carried out a study that aimed to illustrate the influence of including the theory of multiple intelligence in teaching. The study sample was a selection of adult students studying English as a second language and were distributed into two groups: control and experimental. The first group was taught using the usual method, while the second group was taught using methods based on multiple intelligence including problem-solving activities. Both groups were taught by two teachers. The study showed that students in the experimental group had a better understanding, with higher learning performance and a rise in their motivation towards learning, and used the learning styles that agree with their kind of intelligence. Students' compatibility with their teachers increased, teachers' expectation of students' performance also increased along with an increase of their estimation of their students' abilities and mental capabilities. Baldes et al., (2000) conducted a study to raise students' motivation towards learning by using multiple intelligence and co-operative learning. The study sample consisted of Kindergarten students and the $4^{\text {th }}$ and $6^{\text {th }}$ grade students at two primary schools and one intermediate school. The experiment took 16 weeks, during which students participated in pre and post interviews that were saved and analyzed. The study results indicated that the program reduced undisciplined behaviors and increased students' motivation towards achievement. Janes et al. (2000) studied the impact of a multi-dimensional intervention that includes multiple intelligence, cooperative learning and participating in education on the motivation and achievement of (88) students at the $2^{\text {nd }}$ and $3^{\text {rd }}$ grades from three schools. The intervention period was 12 weeks. At the end of the study, teachers' remarks were collected and students were examined in the study modules that were accomplished during the intervention. The study results indicated that including multiple intelligence in teaching has a positive effect on the relevant classes. There was a decrease in the accumulated tasks among students. The results also detected an improvement in students' attitudes towards their schools and towards themselves. Teachers also observed that co-operative learning and multiple intelligence were successfully adopted as tools to increase students' achievement and motivation. Smith et al., 2000 carried out a study in which the effect of using multiple intelligence theory on the $10^{\text {th }}$ grade achievement at Tennessee for English, Science, Mathematics and Social studies was evaluated. The study sample consisted of 82 students equally divided into two: control and experimental groups. To collect data, an evaluation instrument consisting of 28 paragraphs was used. The instrument was checked before and after the experiment for each course. The data was analyzed by using factorial analysis and the multi regression coefficient. The study showed that the multiple intelligence theory was not effective in the meta-cognitive activities and in the academic success of 
students. Rojalla \& Margison (2004) investigated the relationship of multiple intelligence with general efficiency and problem solving. The study sample consisted of 484 subjects on whom the multiple intelligence scales, the general efficiency scale, and the scale of problem solving in teaching situations were applied. By using canonical correlations and variance analysis, the results showed a significant positive correlation between multiple intelligence and general efficiency and problem solving ability. There was a significant effect of experience on problem solving. Ozdener \& Ozcoban (2004) carried out a study with the aim of comparing traditional learning methods with a learning model based on multiple intelligence at classes where computer science is taught for community college students. At the beginning, students were divided into groups: traditional and based on the model. The students' achievement scores were recorded through a particular pre-test that was prepared for this purpose. The model was applied on the students after being classified with it according to their scores. The group that was based on the learning projects were divided into two minor groups: students of the same kind of intelligence (similar in dominant kinds of intelligence), and students of different kinds of intelligence (different in dominant kinds of intelligence) This was determined through a general impression (int. profile). Afterwards, the first group was taught (the traditional group) by using the usual teaching method, and the second group by using multiple intelligence method. This study was applied on 75 students of a private university at Istanbul/Turkey, studying PowerPoint MS at various sections. Achievement test was administered on the sample after they were subjected to the two previous learning methods. By comparing students' results from the test in the pretest and post-test, there was an increase in achievement- scores average-for the first traditional group of seven points, while the second group, based on multiple intelligence obtained 17 points. Through conducting the statistical treatment on both groups by using t-test, significant differences were observed for the benefit of the learning method based on multiple intelligence. The results also indicated having significant differences in achievement between students of similar kinds of intelligence, and those of different kinds of intelligence for the benefit of students of similar kinds of intelligence. The researchers summed up the results by saying that a learning model based on multiple intelligence has a positive effect on students' success. Wahibi (2004) aimed to determine the relationship between multiple intelligence and the locus of control among students from the University of Jordan on one hand, and their motivation for achievement on the other hand. The study sample consisted of 388 male and female students that were randomly chosen. The study applied three instruments of assessment: Motivation to Achieve Test, and multiple intelligence lists. To validate the study hypotheses, the correlation coefficient 
was produced among variables, multi regression coefficient that has an effect in interpreting motivation of achievement. The results of this study showed that motivation of achievement had a significant correlation with multiple intelligence. Meanwhile the motivation to achieve was not significantly correlated with the remaining variables of the study. The results of this study also showed that motivation to achieve was predicted through some of the kinds of multiple intelligence (bodily-kinesthetic, interpersonal, intrapersonal and natural- and also through the external locus of control. Finally, Awad (2009) carried out a study that aimed to investigate the effect of a teaching strategy based on multiple intelligence theory in understanding physics concepts and scientific attitudes, the ability to solve problems among primary stage students. The study sample consisted of (127) male and female students from two schools at the UNRWA southern Amman district/Jordan, and were distributed into four groups: two control groups who were taught in the usual method and two experimental groups who were subject to a training program based on multiple intelligence theory prepared by the researcher. In her study, the researcher employed three instruments: Understanding Physics concepts Test, Scientific Attitudes Scale, Problemsolving Ability Test. The study concluded that there was a significant difference in students' performance in the three scales that can be ascribed to the teaching strategy based on multiple intelligence theory, while there was no effect of interaction between such strategy and gender on understanding physics concepts or on their scientific attitudes, or on the ability to solve problems among primary stage students. The study recommended the necessity of focusing on the employment of multiple intelligence strategies at the various classes and subjects. More studies should be conducted to test the effect of teaching based on multiple intelligence theory on scientific and creative thinking and their relation with students' type of intelligence. From the results of the previous studies about multiple intelligence, we conclude that some of these studies agree on the positive effect of multiple intelligence theory for improving students' achievement, and acquiring the skills of basic science (Awad,2009; Ozdener \& Ozcoban (2004; Janes et al.(2000)). Meanwhile, one study only focused on the impact of teaching strategies based on multiple intelligence on improving students' behavior (Janes et al., 2000). The results of these studies varied regarding the impact of teaching strategies based on multiple intelligence on students' attitudes towards scientific materials or the variance of achievement according to gender (Awad, 2009; Janes et al., 2000). The results of some of these studies indicated a positive impact of teaching employing multiple intelligence in teaching on students' motivation to learn(Christon\&Kennedy,1999; Baldes et al.,2000; Janes et al.,2000).One study only emphasized having a significant positive correlation between multiple intelligence, the general 
self-competence and problem solving (Rogalla \& Margison,2004). A few studies investigated the impact of teaching strategies based on multiple intelligence on students' problem- solving abilities (Awad, 2009). One study only (Smith et al., 2000) evaluated the impact of multiple intelligence on students' academic achievement in mathematics. The study detected that the multiple intelligence theory was not effective in meta-cognitive activities and in the academic success of students.

\section{Methods and Procedures Study Sample}

The study subjects were selected from the College of Education students at Dammam University at the Eastern Area of Saudi Arabia. The sample was chosen for several reasons: the place where the researcher works, which facilitates applying the study procedures and following them up, the availability of facilities and materials necessary to apply the study at the College of Education at Jubail, one of the Colleges of Education at Dammam University where there are a number of Colleges of Education affiliated to Al-Dammam University. Nevertheless, the College of Education at Jubail receive students from various areas at the Eastern District, which provides different cultures and diverse environments.

\section{Study Instruments}

To achieve the study aims, the researcher used a scale to detect the kinds of multiple intelligence among students of the College of Education at Jubail. The scale consisted of () kinds of multiple intelligence. These are covered by (10) survey paragraphs that detected each of the seven kinds of intelligence.

\section{Study Sample}

Table (1) shows the distribution of the study sample according to the specialization variables (preparatory/ scientific, preparatory/ literary, Mathematics, Physics, Computer Science, English and Kindergarten), as a first dependent variable for the independent multiple intelligence variable. The scholastic year variable (preparatory, which is the $1^{\text {st }}$ university year, according to the university education system in Saudi Arabia, $2^{\text {nd }}$ year, $3^{\text {rd }}$ year, and $4^{\text {th }}$ year) as a second dependent variable for the independent multiple intelligence variable.I 
Table (1): Study Sample Distribution according to the study variables

\begin{tabular}{|c|c|c|c|}
\hline Variables & V. Category & Number & Percentage \\
\hline \multirow{4}{*}{ Specialization } & Preparatory/Scientific & 25 & $12.44 \%$ \\
\cline { 2 - 4 } & Preparatory/Literary & 25 & $12.44 \%$ \\
\cline { 2 - 4 } & Mathematics & 31 & $15.42 \%$ \\
\cline { 2 - 4 } & Physics & 30 & $14.93 \%$ \\
\cline { 2 - 4 } & Computer & 30 & $14.93 \%$ \\
\cline { 2 - 4 } & English & 30 & $14.93 \%$ \\
\cline { 2 - 4 } & Kindergarten & 30 & $14.93 \%$ \\
\hline \multirow{5}{*}{ Scholastic Tear } & Total & 50 & $100 \%$ \\
\cline { 2 - 4 } & $1^{\text {st }}$ year(preparatory) & 51 & 24.88 \\
\cline { 2 - 4 } & $2^{\text {nd }}$ Year & 50 & $24.37 \%$ \\
\cline { 2 - 4 } & $3^{\text {rd }}$ Year & 50 & $24.88 \%$ \\
\cline { 2 - 4 } & $4^{\text {th }}$ Year & 201 & $100 \%$ \\
\cline { 2 - 4 } & Total & & \\
\hline
\end{tabular}

\section{Reliability of the Multiple Intelligence Survey List}

The researcher applied the Multiple Intelligence Survey List on an exploratory sample of (35) female students from the study population and out of the study sample. Reliability of the multiple intelligence survey list was collected by using the method of internal consistency, according to Chronbach Alpha. Table (2) shows the reliability factors of the multiple intelligence survey list.

Table (2): Reliability factors of the multiple intelligence survey list according to the method of internal consistency (Chronbach Alpha)

\begin{tabular}{|c|c|c|}
\hline No. & Areas & Reliability Values(Alpha) \\
\hline 1. & Musical Intelligence & 0.837 \\
\hline 2. & Mathematical - Logical Intelligence & 0.813 \\
\hline 3. & $\begin{array}{c}\text { Interpersonal Intelligence } \\
\text { (Social) }\end{array}$ & 0.797 \\
\hline 4. & Bodily-Kinesthetic Intelligence & 0.802 \\
\hline 5. & Linguistic Intelligence & 0.842 \\
\hline 6. & Intrapersonal Intelligence & 0.854 \\
\hline 7. & Visual Intelligence & 0.844 \\
\hline \multicolumn{2}{|c|}{ Common multiple intelligence } \\
\hline
\end{tabular}

The researcher considers that the reliability factors are high, appropriate and adequate for the purposes of the current study.

\section{Statistical Treatment}

To answer the study questions, the following statistical treatments were used:

- To answer the first question of detecting the kinds of multiple intelligence common among the female students of the College of Education at the University of Dammam, means and standard deviations were used. 
- $\quad$ To answer the second and third questions of detecting the difference in the kinds of Multiple Intelligence Common among College of Education Students at Dammam University, according to the variables of university specialization and scholastic year, One Way ANOVA analysis was used. In case the results showed differences ascribed to the study variables, the researcher conducted post comparisons using LSD Method.

- $\quad$ To answer the fourth study question of detecting the impact of interaction between university specialization and scholastic year variables on the difference of the Multiple Intelligence Common among College of Education students at Dammam University, TWO WAY ANOVA analysis was used.

- To answer the fifth study question of detecting the correlation coefficient relationship between the types of Multiple Intelligence Common among College of Education students at Dammam University and their Grade Point Average (GPA), Pearson correlation coefficient was used.

\section{Procedures}

To achieve the study aims, the following procedures were followed:

First, choosing the sample intentionally, since the aim of choosing the College of Education at Jubail and distributing it randomly is to address students randomly wherever they are at college, whether at lectures or the public library, or at any other place. Second, applying the multiple intelligence scale on a sample that is randomly selected from the students of the College of Education at Jubail with their various specializations. Third, tabulate students' responses on the 10 indicators for each of the seven kinds of intelligence with a total of 70 indices, with each of them being the scale for detecting the seven kinds of multiple education according to the criteria that gives the indicator which the student responded to one degree. As for the indicator which the student did not respond to (left empty), it was not given any degree. Fourth, data was collected and tabulated in tables prepared for that purpose. Data was entered into the computer to be statistically treated by using (SPSS) to produce the results.

\section{Study Design and Statistical treatment Study Approach}

The study investigated multiple intelligence on a randomly selected sample from the students of the College of Education at Jubail in their various specializations. Therefore, the approach adopted in the study is a descriptive survey incomprehensive approach through the application of the multiple intelligence inventory. 


\section{Study Variables}

First, Independent variable: multiple intelligence. Second, Dependent variables: specialization, scholastic year and GPA

\section{Statistical Treatment}

Appropriate statistical treatments were used to answer the study questions as follows:

- $\quad$ To answer the main study question, means, standard deviations and percentages of multiple intelligence were calculated for the students of the College of Education at the University of Dammam.

To answer the first minor question, means, standard deviations and percentages of multiple intelligence were calculated on the common multiple education scale for the students of the College of Education at the University of Dammam at the Eastern District of Saudi Arabia. One Way ANOVA was calculated to detect the significant difference of the responses of students from the College of Education at the University of Dammam on the multiple intelligence survey list, according to the variable of university specialization. Post comparisons were produced by using LSD method to detect the source of difference in the responses of students from the College of Education at the University of Dammam on the musical intelligence and mathematical logical intelligence, according to the variable of university specialization.

- $\quad$ To answer the second minor question means, standard deviations of the responses of students from the College of Education at the University of Dammam on the multiple intelligence survey list, according to the variable of scholastic year. One Way ANOVA was calculated to detect the significant difference of the responses of students from the College of Education at the University of Dammam on the multiple intelligence survey list, according to the variable of scholastic year. Post comparisons were produced by using LSD method to detect the source of difference in the responses of students from the College of Education at the University of Dammam on the musical intelligence, according to the variable of scholastic year.

- To answer the third minor question, TWO WAY ANOVA was produces to detect the impact of interaction between university specialization and scholastic year variables on the female students at the College of Education / Dammam University on the multiple intelligence scale list.

- $\quad$ To answer the fourth minor question, Pearson correlation coefficient was used to detect the relation between the kinds of Multiple Intelligence Common among College of Education students at Dammam University and their Grade Point Average (GPA). 


\section{Results}

The current study aimed to answer the following main question: ((What are the types of Multiple Intelligence Common among College of Education students at Dammam University and their Relationship with specialization, scholastic Year and Grade Point Average (GPA)?)). The following hypotheses emerged from this minor question: There is no statistical significance at the level of $(\alpha=0.05)$ in the modified means that can be ascribed to specialization, scholastic Year and Grade Point Average (GPA).

- $\quad$ Results related to knowing "the Kinds of Multiple Intelligence Common among the Students of the Faculty of Education at the University of Dammam”.

To answer the main study question, means, standard deviations and percentages of the responses of students of the college of Education at the University of Dammam to the survey list that measures the seven kinds of multiple intelligence. Table (3) shows the kinds of multiple intelligence common among students of the College of Education / University of Dammam

Table (3): Means, SD and Percentages of Multiple Intelligence among Students of the College of Education at Jubail/ University of Dammam

\begin{tabular}{|c|c|c|c|c|}
\hline Order & Areas & Means & SD & Percentage \\
\hline 1. & Intrapersonal Intelligence & 6.78 & 1.91 & $67.8 \%$ \\
\hline 2. & $\begin{array}{c}\text { Mathematical-logic } \\
\text { Intelligence }\end{array}$ & 5.69 & 1.98 & $56.9 \%$ \\
\hline 3. & Visual Intelligence & 5.56 & 2.23 & $55.6 \%$ \\
\hline 4. & Linguistic Intelligence & 5.48 & 1.95 & $54.8 \%$ \\
\hline 5. & Interpersonal Intelligence & 5.43 & 1.63 & $54.3 \%$ \\
\hline 6. & Bodily-Kinesthetic Intelligence & 5.4 & 2.25 & $54.0 \%$ \\
\hline 7. & Musical Intelligence & 4.79 & 1.92 & $47.9 \%$ \\
\hline & Multiple Intelligence & 39.11 & 9.40 & $55.9 \%$ \\
\hline
\end{tabular}

Table (3) shows that the means of the communality of multiple intelligence among students of the College of Education at Jubail/ University of Dammam was (39.11) with a standard deviation of (9.40) and a percentage of (55.9\%). The most common kind of intelligence among students is intrapersonal intelligence at the first place with a means of (6.78) with a standard deviation of (1.91) and a percentage of (67.8\%).Mathematical - logical intelligence was placed second in communality with a means of (5.69) with a standard deviation of (1.89) and a percentage of (56.9\%). Visual intelligence was placed third in communality with a means of (5.65) with a standard deviation of (2.23) and a percentage of (55.6\%).The least communality kind of intelligence was musical intelligence which was placed final in communality with a means of (4.79) with a standard deviation of (1.92) and a percentage of (47.9\%). 
Results related to answering the first minor question which states: "Is there a difference in the kinds of Multiple Intelligence Common among College of Education Students at Dammam University that is ascribed to university specialization?" To detect the difference in the kinds of Multiple Intelligence Common among the College of Education students at Dammam University in the light of university specialization, means and standard deviations of the responses of students to the survey list that measures the seven kinds of multiple intelligence, according to university specialization variable reparatory/Scientific, Preparatory/ Literary, Mathematics, Physics, Computer Science, English and Kindergarten) were produced. Table (4) shows the results

Table (4): Means and standard deviations of the responses of the College of Education students at the University of Dammam to the Multiple Intelligence Survey List according to the university specialization variable

\begin{tabular}{|c|c|c|c|c|c|c|c|c|c|c|c|c|c|c|}
\hline & \multicolumn{2}{|c|}{ Prep/Scientific } & \multicolumn{2}{|c|}{ Prep/Literary } & \multicolumn{2}{|c|}{ Mathematics } & \multicolumn{2}{|c|}{ Physics } & \multicolumn{2}{|c|}{$\begin{array}{l}\text { Computer } \\
\text { Science }\end{array}$} & \multicolumn{2}{|c|}{ English } & \multicolumn{2}{|c|}{ Kindergarten } \\
\hline $\begin{array}{c}\text { Musical } \\
\text { Intelligence }\end{array}$ & 5.16 & 2.12 & 4.44 & 1.58 & 4.35 & 1.94 & 4.57 & 1.94 & 5.50 & 1.76 & 5.40 & 1.90 & 4.10 & 1.84 \\
\hline $\begin{array}{l}\text { Mathematical- } \\
\text { Logical }\end{array}$ & 6.28 & 2.07 & 5.52 & 1.76 & 6.39 & 1.86 & 5.03 & 2.19 & 6.60 & 1.38 & 4.93 & 2.07 & 5.10 & 1.83 \\
\hline $\begin{array}{c}\text { Interpersonal } \\
\text { (Social) }\end{array}$ & 5.16 & 1.11 & 5.64 & 1.55 & 5.48 & 1.71 & 5.10 & 1.73 & 5.87 & 1.80 & 5.30 & 1.62 & 5.43 & 1.72 \\
\hline Linguistic & 5.76 & 1.64 & 5.24 & 1.71 & 5.68 & 1.42 & 5.27 & 1.51 & 6.07 & 2.12 & 5.07 & 1.95 & 5.27 & 2.85 \\
\hline Intrapersonal & 6.00 & 2.24 & 6.96 & 1.97 & 7.03 & 1.62 & 6.50 & 2.01 & 7.20 & 1.56 & 6.93 & 1.87 & 6.70 & 2.02 \\
\hline Visual & 5.28 & 2.76 & 5.48 & 1.83 & 5.42 & 2.19 & 5.53 & 2.10 & 5.77 & 2.03 & 5.93 & 2.36 & 5.43 & 2.42 \\
\hline $\begin{array}{c}\text { Multiple } \\
\text { Intelligences } \\
\text { (Total) } \\
\end{array}$ & 39.00 & 9.20 & 38.80 & 9.68 & 39.84 & 8.74 & 37.17 & 9.87 & 42.60 & 8.11 & 39.20 & 9.88 & 37.07 & 10.01 \\
\hline
\end{tabular}

Means shown in table (4) show apparent differences in the means of students' response to the survey list of multiple intelligence in the light of university specialization variable on each area of the seven kinds of intelligence and the total kinds of intelligence. To know the statistical significance level of differences in the means of students' response to the survey list of multiple intelligence in the light of university specialization variable : Preparatory/ Scientific, Preparatory/Literary, Mathematics, Physics, Computer, English, Kindergarten), ONE WAY ANOVA was used. Table (5) shows the results. 
Table (5): Results of ANOVA analysis to detect the difference significance of the College of Education at the Dammam University students' responses at the multiple intelligence survey list according to the university specialization variable

\begin{tabular}{|c|c|c|c|c|c|c|}
\hline Areas & $\begin{array}{l}\text { Source of } \\
\text { Variance }\end{array}$ & $\begin{array}{c}\text { Square } \\
\text { Total }\end{array}$ & $\begin{array}{c}\text { Freedom } \\
\text { Degree }\end{array}$ & $\begin{array}{l}\text { Square } \\
\text { Means }\end{array}$ & $\begin{array}{c}\mathrm{F} \\
\text { Value }\end{array}$ & $\begin{array}{l}\text { Significance } \\
\text { Level }\end{array}$ \\
\hline \multirow[t]{3}{*}{$\begin{array}{c}\text { Musical } \\
\text { Intelligence) }\end{array}$} & $\begin{array}{l}\text { Among } \\
\text { groups }\end{array}$ & 54.418 & 6 & 9.070 & & \multirow[t]{3}{*}{$* 0.020$} \\
\hline & $\begin{array}{l}\text { Inside } \\
\text { groups }\end{array}$ & 683.383 & 194 & 3.523 & & \\
\hline & Total & 737.801 & 200 & & & \\
\hline \multirow[t]{3}{*}{$\begin{array}{l}\text { Mathematical- } \\
\text { Logical }\end{array}$} & $\begin{array}{l}\text { Among } \\
\text { groups }\end{array}$ & 89.886 & 6 & 14.981 & & \multirow[t]{3}{*}{$* 0.001$} \\
\hline & $\begin{array}{l}\text { Inside } \\
\text { groups }\end{array}$ & 695.368 & 194 & 3.584 & & \\
\hline & Total & 785.254 & 200 & & & \\
\hline \multirow[t]{3}{*}{ Intrapersonal } & $\begin{array}{l}\text { Among } \\
\text { groups }\end{array}$ & 12.509 & 6 & 2.085 & & \multirow[t]{3}{*}{0.584} \\
\hline & $\begin{array}{l}\text { Inside } \\
\text { groups }\end{array}$ & 516.695 & 194 & 2.663 & & \\
\hline & Total & 529.204 & 200 & & & \\
\hline \multirow[t]{3}{*}{$\begin{array}{l}\text { Bodily- } \\
\text { kinesthetic }\end{array}$} & $\begin{array}{l}\text { Among } \\
\text { groups }\end{array}$ & 9.117 & 6 & 1.520 & & \multirow[t]{3}{*}{0.940} \\
\hline & $\begin{array}{l}\text { Inside } \\
\text { groups }\end{array}$ & 1007.042 & 194 & 5.191 & & \\
\hline & Total & 1016 & 200 & & & \\
\hline \multirow[t]{3}{*}{ Linguistic } & $\begin{array}{l}\text { Among } \\
\text { groups }\end{array}$ & 22.788 & 6 & 3.798 & & \multirow[t]{3}{*}{0.427} \\
\hline & $\begin{array}{l}\text { Inside } \\
\text { groups }\end{array}$ & 737.361 & 194 & 3.801 & & \\
\hline & Total & 760.149 & 200 & & & \\
\hline \multirow[t]{3}{*}{ Intrapersonal } & $\begin{array}{l}\text { Among } \\
\text { groups }\end{array}$ & 26.531 & 6 & 4.422 & & \multirow[t]{3}{*}{0.295} \\
\hline & $\begin{array}{l}\text { Inside } \\
\text { groups }\end{array}$ & 700394 & 194 & 3.610 & & \\
\hline & Total & 726.925 & 200 & & & \\
\hline \multirow[t]{3}{*}{ Visual } & $\begin{array}{l}\text { Among } \\
\text { groups }\end{array}$ & 8.697 & 6 & 1.449 & \multirow[t]{3}{*}{0.286} & \multirow[t]{3}{*}{0.943} \\
\hline & $\begin{array}{l}\text { Inside } \\
\text { Groups }\end{array}$ & 984.895 & 194 & & & \\
\hline & Total & 993.592 & 200 & & & \\
\hline \multirow{3}{*}{$\begin{array}{c}\text { Multiple } \\
\text { Intelligence } \\
\text { (Total) }\end{array}$} & $\begin{array}{l}\text { Among } \\
\text { groups }\end{array}$ & 623.365 & 6 & 103.894 & \multirow[t]{3}{*}{1.183} & \multirow[t]{3}{*}{0.317} \\
\hline & $\begin{array}{l}\text { Inside } \\
\text { Groups }\end{array}$ & 17042.227 & 194 & 87.847 & & \\
\hline & Total & & & & & \\
\hline
\end{tabular}

Results shown in table (5) indicate that there are significant differences among the means of responses of female students at the College 
of Education/ University of Dammam in musical intelligence and mathematical logical intelligence on the survey list of multiple intelligence that can be ascribed to university specialization variable. The two $\mathrm{F}$ values were (2.575, and (4.180) respectively. These two values are significant at the level $(0.05 \geq \alpha)$, while the results at the same table indicate that there are significant differences among the means and the response of the students of the Faculty of Education/university of Dammam to the remaining kinds of intelligence provided in the list of multiple intelligence survey. To detect the source of difference of having statistical significance of the university specialization variable in the responses of female students at the College of Education/ University of Dammam in musical intelligence and mathematical logical intelligence, post comparisons were carried out by using LSD method, as illustrated in table (6)

Table (6): LSD comparison results to detect the source of difference of having the university specialization variable in the responses of female students at the College of

Education/ University of Dammam in musical intelligence and mathematical logical intelligence

\begin{tabular}{|c|c|c|c|c|c|c|c|c|c|}
\hline \multirow[t]{2}{*}{ Area } & \multicolumn{2}{|c|}{$\begin{array}{c}\text { University } \\
\text { Specialization }\end{array}$} & $\begin{array}{l}\text { Prep. } \\
\text { Scienti }\end{array}$ & $\begin{array}{l}\text { Prep. } \\
\text { Litera }\end{array}$ & $\begin{array}{c}\text { Mat } \\
\mathrm{h}\end{array}$ & $\begin{array}{l}\text { Physi } \\
\text { cs }\end{array}$ & $\begin{array}{l}\text { Comput } \\
\text { er }\end{array}$ & $\begin{array}{l}\text { Engli } \\
\text { sh }\end{array}$ & $\begin{array}{c}\text { Kindergar } \\
\text { ten }\end{array}$ \\
\hline & \multicolumn{2}{|l|}{ M } & 5.16 & 4.44 & 4.3 & 4.57 & 5.50 & 5.40 & 4.10 \\
\hline \multirow[t]{6}{*}{$\begin{array}{c}\text { Musical } \\
\text { Intellige } \\
\text { nce }\end{array}$} & $\begin{array}{c}\text { Prep. } \\
\text { Scientific }\end{array}$ & 5.16 & - & 0.72 & $\begin{array}{c}0.8 \\
1\end{array}$ & 0.59 & 0.34 & 0.24 & *1.06 \\
\hline & $\begin{array}{c}\text { Prep. } \\
\text { Literary }\end{array}$ & 4.44 & - & - & $\begin{array}{c}0.0 \\
9\end{array}$ & 0.13 & *1.06 & 0.96 & 0.34 \\
\hline & Math & 4.35 & - & - & - & 0.21 & *1.15 & *1.05 & 0.25 \\
\hline & Physics & 4.57 & - & - & - & - & 0.93 & 0.83 & 0.47 \\
\hline & Computer & 5.50 & - & - & - & - & - & 0.10 & $* 1.40$ \\
\hline & English & 5.40 & - & - & - & - & - & - & $* 1.30$ \\
\hline \multirow{8}{*}{$\begin{array}{c}\text { Mathem } \\
\text { atical- } \\
\text { Logical } \\
\text { Intellige } \\
\text { nce }\end{array}$} & $\begin{array}{c}\text { University } \\
\text { Specializati } \\
\text { on }\end{array}$ & & $\begin{array}{l}\text { Prep. } \\
\text { Scienti } \\
\text { fic }\end{array}$ & $\begin{array}{l}\text { Prep. } \\
\text { Litera } \\
\text { ry }\end{array}$ & $\begin{array}{c}\text { Mat } \\
\mathrm{h}\end{array}$ & $\begin{array}{c}\text { Physi } \\
\text { CS }\end{array}$ & $\begin{array}{l}\text { Comput } \\
\text { er }\end{array}$ & $\begin{array}{l}\text { Engli } \\
\text { sh }\end{array}$ & $\begin{array}{c}\text { Kindergar } \\
\text { ten }\end{array}$ \\
\hline & & $\mathrm{M}$ & 6.28 & 5.52 & $\begin{array}{c}6.3 \\
9\end{array}$ & 5.03 & 6.60 & 4.93 & 5.10 \\
\hline & $\begin{array}{c}\text { Prep. } \\
\text { Scientific }\end{array}$ & 6.28 & - & 0.76 & $\begin{array}{c}0.1 \\
1\end{array}$ & $* 1.25$ & 0.32 & $* 1.35$ & *1.18 \\
\hline & $\begin{array}{c}\text { Prep. } \\
\text { Literary }\end{array}$ & 5.52 & - & - & $\begin{array}{c}0.8 \\
7 \\
\end{array}$ & 0.49 & *1.08 & 0.59 & 0.42 \\
\hline & Math & 6.39 & - & - & - & $* 1.35$ & 0.21 & *1.45 & $* 1.29$ \\
\hline & Physics & 5.03 & - & - & - & - & $* 1.57$ & 0.10 & 0.07 \\
\hline & Computer & 6.60 & - & - & - & - & - & 81.67 & $* 1.50$ \\
\hline & English & 4.93 & - & - & - & - & - & - & 0.17 \\
\hline
\end{tabular}

Results provided in table (6) show that the source of the significant differences among responses of female students at the College of Education/ University of Dammam in musical intelligence was between the responses 
of the preparatory scientific students on the one hand and the responses of kindergarten students on the other hand, for the benefit of the students of preparatory /scientific. Differences were also significant among the responses of the computer students on the one hand, and the responses of preparatory/ literary, Mathematics and Kindergarten students on the other hand for the benefit of the students of Computer Science. Differences were also significant the responses of English students on the one hand, and the responses of Mathematics and Kindergarten students on the other hand for the benefit of the students of English. This result indicates the communality of musical intelligence among the students of preparatory/ scientific to a greater degree of their colleagues in Kindergarten specialization. Musical intelligence is also common among the students of Computer Science to a greater degree of their colleagues of Preparatory / Literary, Mathematics and Kindergarten. Musical intelligence is also common among the students of English to a greater degree of their colleagues of Mathematics and Kindergarten specialization. The results provided in table (6) also show that the source of the significant differences among responses of female students at the College of Education/ University of Dammam in mathematicallogical intelligence was between the responses of the preparatory scientific students on the one hand, and the responses of Physics, English and Kindergarten students on the other hand for the benefit of the students of preparatory /scientific. Differences were also significant, the responses of the Mathematics students on the one hand and the responses of Physics, English and Kindergarten students on the other hand for the benefit of the students of Mathematics. Differences were also significant among the responses of the Computer Science students on the one hand and the responses of preparatory/ literary, Physics, English and Kindergarten students on the other hand for the benefit of the students of Computer Science. This result indicates the communality of mathematical-logical intelligence among the students of preparatory/ scientific, Mathematics and Computer science to a greater degree of their colleagues in Physics, English and Kindergarten specialization.

Results related to answering the second minor question that states: Is there difference in the kinds of Multiple Intelligence Common among College of Education Students at Dammam University that is ascribed to scholastic year? To detect the difference in the kinds of Multiple Intelligence Common among College of Education Students at Dammam University according to the scholastic year, means and standard deviation of students' responses to the multiple intelligence survey list for the scholastic year $\left(1^{\text {st }}, 2\right.$ nd, 3rd, and 4 th) were calculated. Table (7) shows the results: 
Table (7): Means and standard deviation of students' responses to the multiple intelligence survey list according to the scholastic year

\begin{tabular}{|c|c|c|c|c|c|c|c|c|}
\hline \multicolumn{2}{|c|}{ Scholastic Year } & \multicolumn{2}{|c|}{$1^{\text {st }}$ Year } & \multicolumn{2}{|c|}{$2^{\text {nd }}$ year } & \multicolumn{2}{|c|}{$3^{\text {rd }}$ Year } & \multicolumn{2}{c|}{$4^{\text {th }}$ Year } \\
\cline { 1 - 9 } Areas & Means & SD & Means & SD & Means & SD & Means & SD \\
\hline $\begin{array}{c}\text { Musical } \\
\text { Intelligence }\end{array}$ & 4.80 & 1.88 & 5.45 & 1.84 & 4.90 & 1.89 & 3.98 & 1.83 \\
\cline { 1 - 9 } $\begin{array}{c}\text { Mathematical- } \\
\text { Logical } \\
\text { Intelligence }\end{array}$ & 5.90 & 1.94 & 5.84 & 2.19 & 5.64 & 1.87 & 5.36 & 1.92 \\
\hline $\begin{array}{c}\text { Interpersonal } \\
\text { (Social) } \\
\text { Intelligence }\end{array}$ & 5.40 & 1.36 & 5.61 & 1.66 & 5.26 & 1.80 & 5.44 & 1.68 \\
\hline $\begin{array}{c}\text { Bodily-kinesthetic } \\
\text { Intelligence }\end{array}$ & 5.44 & 2.38 & 5.63 & 2.06 & 5.30 & 2.43 & 5.22 & 2.17 \\
\hline $\begin{array}{c}\text { Linguistic } \\
\text { Intelligence }\end{array}$ & 5.50 & 1.68 & 5.82 & 1.71 & 5.46 & 2.07 & 5.12 & 2.27 \\
\hline $\begin{array}{c}\text { Intrapersonal } \\
\text { Intelligence }\end{array}$ & 6.48 & 2.14 & 7.02 & 1.90 & 6.94 & 1.87 & 6.66 & 1.70 \\
\hline Visual Intelligence & 5.38 & 2.32 & 6.22 & 2.07 & 5.24 & 2.30 & 5.38 & 2.15 \\
\hline $\begin{array}{c}\text { Multiple } \\
\text { Intelligence } \\
\text { 9Total) }\end{array}$ & 38.90 & 9.34 & 41.59 & 8.764. & 38.74 & 9.89 & 37.16 & 9.30 \\
\hline
\end{tabular}

Means provided in table (7) indicate that there are apparent differences in the means of students' responses to the multiple intelligence survey list, according to the scholastic year on each of the seven kinds of multiple intelligence and all the kinds of multiple intelligence collectively. One Way ANOVA was used to produce significance difference of students' responses to the multiple intelligence survey list according to the scholastic year $\left(1^{\text {st }}, 2^{\text {nd }}, 3^{\text {rd }}, 4^{\text {th }}\right)$. Table (8) shows the results:

Table (8): ANOVA results detecting the difference significance in students' responses to the multiple intelligence survey list according to the scholastic year

\begin{tabular}{|c|c|c|c|c|c|c|}
\hline Areas & $\begin{array}{c}\text { Variance } \\
\text { Source }\end{array}$ & $\begin{array}{c}\text { Total } \\
\text { Squares }\end{array}$ & $\begin{array}{c}\text { Freedom } \\
\text { Degrees }\end{array}$ & $\begin{array}{c}\text { Squares } \\
\text { Means }\end{array}$ & $\begin{array}{c}\mathrm{F} \\
\text { Value }\end{array}$ & $\begin{array}{c}\text { Significance } \\
\text { level }\end{array}$ \\
\hline \multirow[t]{3}{*}{$\begin{array}{c}\text { Musical } \\
\text { Intelligence }\end{array}$} & $\begin{array}{l}\text { Among } \\
\text { groups }\end{array}$ & 55.694 & 3 & 18.565 & \multirow[t]{3}{*}{5.362} & \multirow[t]{3}{*}{$* 0.001$} \\
\hline & $\begin{array}{l}\text { Inside } \\
\text { groups }\end{array}$ & 682.107 & 197 & 3.462 & & \\
\hline & Total & 737.801 & 200 & & & \\
\hline \multirow{3}{*}{$\begin{array}{l}\text { Mathematical- } \\
\text { Logical } \\
\text { Intelligence }\end{array}$} & $\begin{array}{l}\text { Among } \\
\text { groups }\end{array}$ & 8.969 & 3 & 2.990 & \multirow[t]{3}{*}{0.759} & \multirow[t]{3}{*}{0.519} \\
\hline & $\begin{array}{l}\text { Inside } \\
\text { groups }\end{array}$ & 776.285 & 197 & 3.941 & & \\
\hline & Total & 785.254 & 200 & & & \\
\hline \multirow{3}{*}{$\begin{array}{l}\text { Interpersonal } \\
\text { (social) } \\
\text { Intelligence }\end{array}$} & $\begin{array}{l}\text { Among } \\
\text { groups }\end{array}$ & 3.107 & 3 & 1.036 & \multirow[t]{3}{*}{0.388} & \multirow[t]{3}{*}{0.762} \\
\hline & $\begin{array}{l}\text { Inside } \\
\text { groups }\end{array}$ & 526.097 & 197 & 2.671 & & \\
\hline & Total & 529.204 & 200 & & & \\
\hline
\end{tabular}




\begin{tabular}{|c|c|c|c|c|c|c|}
\hline $\begin{array}{c}\text { Bodily- } \\
\text { Kinesthetic }\end{array}$ & $\begin{array}{l}\text { Among } \\
\text { groups }\end{array}$ & 4.838 & 3 & 1.613 & \multirow[t]{3}{*}{0.314} & \multirow[t]{3}{*}{0.815} \\
\hline \multirow[t]{2}{*}{ Intelligence } & $\begin{array}{l}\text { Inside } \\
\text { groups }\end{array}$ & 1011.322 & 197 & 5.134 & & \\
\hline & Total & 1061.159 & 200 & & & \\
\hline \multirow[t]{3}{*}{$\begin{array}{l}\text { Linguistic } \\
\text { Intelligence }\end{array}$} & $\begin{array}{l}\text { Among } \\
\text { groups }\end{array}$ & 12.537 & 3 & 4.179 & \multirow[t]{3}{*}{1.101} & \multirow[t]{3}{*}{0.350} \\
\hline & $\begin{array}{l}\text { Inside } \\
\text { groups }\end{array}$ & 747.612 & 197 & 3.759 & & \\
\hline & Total & 760.149 & 200 & & & \\
\hline \multirow[t]{3}{*}{$\begin{array}{l}\text { Intrapersonal } \\
\text { Intelligence }\end{array}$} & $\begin{array}{l}\text { Among } \\
\text { groups }\end{array}$ & 9.425 & 3 & 3.142 & \multirow[t]{3}{*}{0.863} & \multirow[t]{3}{*}{0.461} \\
\hline & $\begin{array}{l}\text { Inside } \\
\text { groups }\end{array}$ & 717.500 & 197 & 3.642 & & \\
\hline & Total & 726.925 & 200 & & & \\
\hline \multirow[t]{3}{*}{$\begin{array}{c}\text { Visual } \\
\text { Intelligence }\end{array}$} & $\begin{array}{l}\text { Among } \\
\text { groups }\end{array}$ & 30.285 & 3 & 10.095 & \multirow[t]{3}{*}{2.064} & \multirow[t]{3}{*}{0.106} \\
\hline & $\begin{array}{l}\text { Inside } \\
\text { groups }\end{array}$ & 963.307 & 197 & 4.890 & & \\
\hline & Total & 993.592 & 200 & & & \\
\hline \multirow{3}{*}{$\begin{array}{c}\text { Multiple } \\
\text { Intelligence } \\
\text { (Total) }\end{array}$} & $\begin{array}{l}\text { Among } \\
\text { groups }\end{array}$ & 512.399 & 3 & 170.800 & \multirow[t]{3}{*}{1.962} & \multirow[t]{3}{*}{0.121} \\
\hline & $\begin{array}{l}\text { Inside } \\
\text { groups }\end{array}$ & 17153.193 & 197 & & & \\
\hline & Total & 17665.592 & 200 & & & \\
\hline
\end{tabular}

Results shown in table (8) indicate having a significant difference in the means and standard deviation of students of the College of Education at the University of Dammam responses to musical intelligence on the multiple intelligence survey list that can be ascribed to the scholastic year variable. F Value calculated for that area was (5.362). This value is significant at the level of $(0.05 \geq \alpha)$.Meanwhile, the results shown at the same table indicate that there are no significant differences in the means and standard deviation of students of the College of Education at the University of Dammam responses to the remaining kinds of intelligence on the multiple intelligence survey list. To detect the source of significance differences for the scholastic year variable of students of the College of Education at the University of Dammam responses to musical intelligence, post comparison were conducted using (LSD) method, which is illustrated in Table (9).

Table (9): Results of Post comparison were conducted using (LSD) method to detect the source of differences of students of the College of Education at the University of Dammam responses to musical intelligence according to the scholastic year variable

\begin{tabular}{|c|c|c|c|c|c|}
\hline Scholastic Year & & $1^{\text {st }}$ Year & $2^{\text {nd }}$ Year & $3^{\text {rd }}$ Year & $4^{\mathrm{TH}}$ Year \\
\hline & $\mathrm{M}$ & 4.80 & 5.45 & 4.90 & 3.98 \\
\hline $1^{\text {st }}$ Year & 4.80 & - & 0.65 & 0.10 & 0.82 \\
\hline $2^{\text {nd }}$ Year & 5.45 & - & - & 0.55 & 1.47 \\
\hline $3^{\text {rd }}$ Year & 4,90 & - & - & - & 0.92 \\
\hline
\end{tabular}


Results shown in table (9) indicate that the source of significant differences among the responses of the students of the College of Education/university of Dammam to musical intelligence, were between the responses of the $4^{\text {th }}$ year students on the one hand, and the responses of the $1^{\text {st }}, 2^{\text {nd }}$ and $3^{\text {rd }}$ year students on the other hand for the benefit of the $1^{\text {st }}, 2^{\text {nd }}$ and $3^{\text {rd }}$ year students. This result indicated that the communality of musical intelligence is less among the $4^{\text {th }}$ year students, compared with their colleagues at the other years.

Results related to answering the third minor question that states: Is there difference in the kinds of Multiple Intelligence Common among College of Education Students at Dammam University that is ascribed to interaction between the university specialization and scholastic year variables?. To detect the effect of interaction between the university specialization and scholastic year variables in the communality of multiple intelligence common among College of Education Students at Dammam University, means and standard deviations of students' responses on the multiple intelligence survey list were produced according to the variables of university specialization( Mathematics, Physics, Computer Science, English, and Kindergarten $)$ and scholastic year $\left(2^{\text {nd }}, 3^{\text {rd }}, 4^{\text {th }}\right.$ year $)$. The $1^{\text {st }}$ year students were excluded because they were still at the preparatory year( have not specialized yet).Two way ANOVA was used to detect the interaction between the university specialization and scholastic year variables. Table (10) illustrates the results.

Table (10): Two way ANOVA analysis results to detect the interaction between the university specialization and scholastic year variables to students of the College of Education at the University of Dammam responses on the multiple intelligence survey list

\begin{tabular}{|c|c|c|c|c|c|c|}
\hline Area & $\begin{array}{c}\text { Source of } \\
\text { Variance }\end{array}$ & $\begin{array}{c}\text { Square } \\
\text { Total }\end{array}$ & $\begin{array}{c}\text { Freedom } \\
\text { Degrees }\end{array}$ & $\begin{array}{c}\text { Squares } \\
\text { Means }\end{array}$ & $\begin{array}{c}\mathrm{F} \\
\text { Value }\end{array}$ & $\begin{array}{c}\text { Significance } \\
\text { level }\end{array}$ \\
\hline $\begin{array}{c}\text { Musical } \\
\text { Intelligence }\end{array}$ & $\begin{array}{c}\text { University } \\
\text { specialization x } \\
\text { Scholastic Year }\end{array}$ & 15.666 & 8 & 1.958 & 0.600 & 0.777 \\
\hline $\begin{array}{c}\text { Mathematical- } \\
\text { Logical } \\
\text { Intelligence }\end{array}$ & $\begin{array}{c}\text { University } \\
\text { specialization x } \\
\text { Scholastic Year }\end{array}$ & 26.550 & 8 & 3.319 & 0.929 & 0.495 \\
\hline $\begin{array}{c}\text { Interpersonal } \\
\text { (social) } \\
\text { Intelligence }\end{array}$ & $\begin{array}{c}\text { University } \\
\text { specialization x } \\
\text { Scholastic Year }\end{array}$ & 22.426 & 8 & 2.803 & 0.943 & 0.483 \\
\hline $\begin{array}{c}\text { Bodily- } \\
\text { kinesthetic } \\
\text { Intelligence }\end{array}$ & $\begin{array}{c}\text { University } \\
\text { specialization x } \\
\text { Scholastic Year }\end{array}$ & 20.869 & 8 & 2.609 & 0.504 & 0.851 \\
\hline $\begin{array}{c}\text { Linguistic } \\
\text { Intelligence }\end{array}$ & $\begin{array}{c}\text { University } \\
\text { specialization x } \\
\text { Scholastic Year }\end{array}$ & 62.535 & 8 & 7.817 & 2.016 & $* 0.049$ \\
\hline $\begin{array}{c}\text { Intrapersonal } \\
\text { Intelligence }\end{array}$ & $\begin{array}{c}\text { University } \\
\text { specialization x } \\
\text { Scholastic Year }\end{array}$ & 46.209 & 8 & 5.776 & 1.795 & 0.083 \\
\hline $\begin{array}{c}\text { Visual } \\
\text { Intelligence }\end{array}$ & $\begin{array}{c}\text { University } \\
\text { specialization x }\end{array}$ & 47.137 & 8 & 5.892 & 1.240 & 0.280 \\
\hline
\end{tabular}




\begin{tabular}{|c|c|c|c|c|c|c|}
\hline & Scholastic Year & & & & & \\
\hline $\begin{array}{c}\text { Multiple } \\
\text { Intelligence } \\
\text { (Total) }\end{array}$ & $\begin{array}{c}\text { University } \\
\text { specialization x } \\
\text { Scholastic Year }\end{array}$ & 914.011 & 8 & 114.251 & 1.370 & 0.219 \\
\hline
\end{tabular}

*Significant

Results shown at table (10) indicate that there are no significant differences among the means of the responses of the College of Education/ university of Dammam students on the multiple intelligence survey list that is ascribed to interaction between the university specialization and scholastic year variables, except for having an effect between the university specialization and scholastic year variables on linguistic intelligence, where $\mathrm{F}$ value calculated for this area was (2.016) which is significant at the level of $(0.05 \geq \alpha)$. Figure (1) illustrates the interaction effect between the university specialization and scholastic year variables in the responses of the students of College of Education at the University of Dammam on linguistic intelligence.

Figure (1): A diagram illustrating interaction effect between the university specialization and scholastic year variables in the responses of the students of College of Education at the

University of Dammam on linguistic intelligence

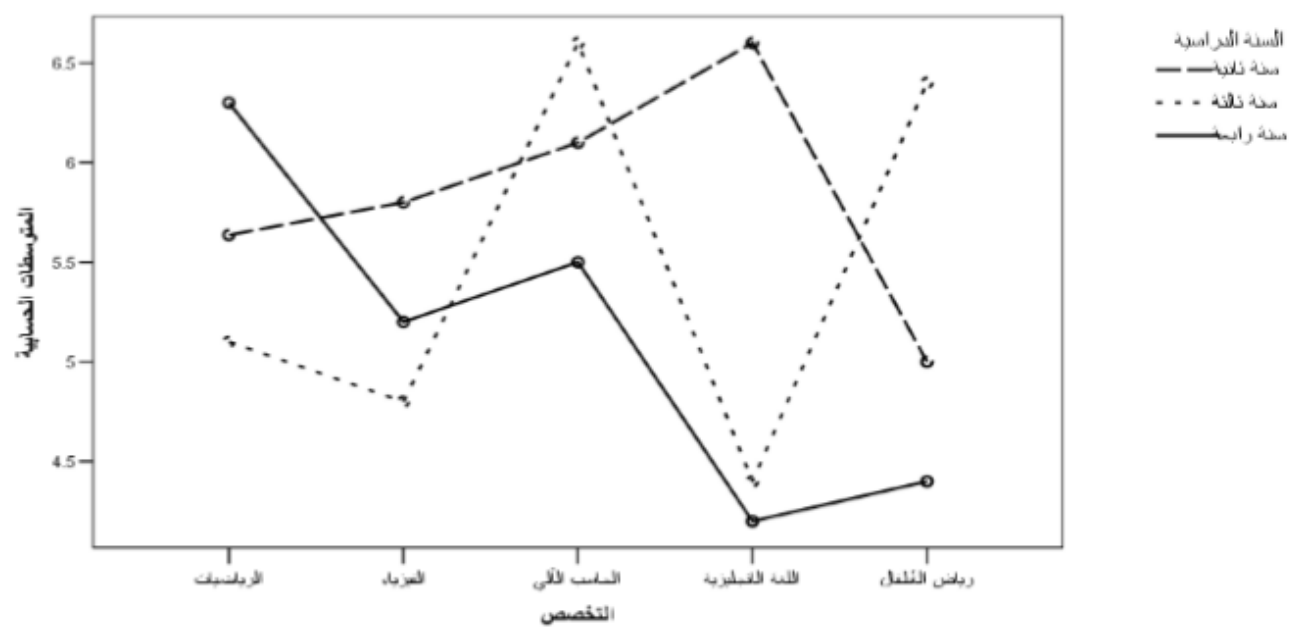

The diagram that illustrates the interaction effect between the university specialization and scholastic year variables in the responses of the students of College of Education at the University of Dammam on linguistic intelligence indicates that linguistic intelligence increases clearly among the $2^{\text {nd }}$ year students of English specialization compared to their colleagues at the $3^{\text {rd }}$ and $4^{\text {th }}$ year. Meanwhile, linguistic intelligence increases clearly among the $3^{\text {rd }}$ year students of the mathematics specialization compared to their colleagues of the $4^{\text {th }}$ year students. 
Results related to the Fourth Minor Question, which states: "Is there a correlative relationship between common kinds of multiple intelligence and the Grade Point Average (GPA) of the students of the College of Education at the University of Dammam?” To answer this question, and for the aim of detecting the correlative relationship between common kinds of multiple intelligence and the Grade Point Average ( GPA) of the students of the College of Education at the University of Dammam, Pearson correlation coefficient was used. Table (11) shows the result.

Table (11): Results of using Pearson Correlation Coefficient to detect the correlative relationship between common kinds of multiple intelligence and the Grade Point Average (

GPA) of the students of the College of Education at the University of Dammam

\begin{tabular}{|c|c|c|c|}
\hline Number & Areas & $\begin{array}{c}\text { Correlation Values between } \\
\text { University Specialization and } \\
\text { GPA }\end{array}$ & $\begin{array}{c}\text { Significance } \\
\text { Level }\end{array}$ \\
\hline 1. & Musical Intelligence & 0.25 & 0.730 \\
\hline 2. & $\begin{array}{c}\text { Mathematical- Logical } \\
\text { Intelligence }\end{array}$ & 0.265 & $0.000^{*}$ \\
\hline 3. & $\begin{array}{c}\text { Interpersonal (social) } \\
\text { Intelligence }\end{array}$ & 0.101 & 0.153 \\
\hline 4. & $\begin{array}{c}\text { Bodily-kinesthetic } \\
\text { Intelligence }\end{array}$ & 0.037 & 0.604 \\
\hline 5. & Linguistic Intelligence & 0.183 & 0.127 \\
\hline 6. & $\begin{array}{c}\text { Intrapersonal } \\
\text { Intelligence }\end{array}$ & 0.108 & 0.262 \\
\hline 7. & Visual Intelligence & 0.079 & $0.027 *$ \\
\hline 8 & Multiple Intelligence & 1.156 & \\
\hline
\end{tabular}

*Significant

Results shown in table (23) indicate that the relationship between musical intelligence and GPA was negative but insignificant. Meanwhile, the remaining kinds of intelligence had a positive but simple relationship with GPA. Results shown in table (11) indicate that the positive relationship between mathematical - logical intelligence and linguistic intelligence and the seven kinds of intelligence in general, and the GPA was simple and significant. The correlation values were (0.265),(0.183), and (0.156) respectively. This result means that there is a simple positive and significant relation between mathematical - logical intelligence and linguistic intelligence and the seven kinds of intelligence in general and the GPA, and that the best correlative relationship was between the mathematical - logical intelligence and the GPA. 
Table (12): Means and standard deviations of mathematical - logical intelligence and the

College of Education at the University of Dammam students' achievement in mathematical courses

\begin{tabular}{|c|c|c|c|c|c|}
\hline \multirow[t]{2}{*}{ Specialization } & \multirow[t]{2}{*}{ Course } & \multicolumn{2}{|c|}{ Achievement } & \multicolumn{2}{|c|}{$\begin{array}{l}\text { Mathematical } \\
\text { Intelligence }\end{array}$} \\
\hline & & Means & S.D & Means & S.D \\
\hline & $\begin{array}{l}\text { Mathematics for } \\
\text { S.E. Teachers }\end{array}$ & 84.3 & 6.1 & 5.52 & 1.76 \\
\hline Preparatory/Scientific & $\begin{array}{c}\text { Educational } \\
\text { Statistics }\end{array}$ & 72.5 & 13.6 & 6.28 & 2.07 \\
\hline \multirow[t]{2}{*}{ Mathematics } & $\begin{array}{c}\text { Design \& } \\
\text { Develop } \\
\text { Mathematics } \\
\text { Lessons }\end{array}$ & 87.6 & 4.9 & \multirow[t]{2}{*}{6.39} & \multirow[t]{2}{*}{1.86} \\
\hline & $\begin{array}{l}\text { Mathematics } \\
\text { Methodology }\end{array}$ & 33.7 & 3.6 & & \\
\hline
\end{tabular}

\section{Conclusion}

The study aimed to detect the kinds of Multiple Intelligence Common among College of Education students at Dammam University for the variables of specialization, scholastic year and GPA as variables of multiple intelligence as an independent variable. To explore the statistical significance of the kinds of multiple intelligence common among College of Education students at Dammam University students according to the interaction between the specialization and the scholastic year, in addition to the strength of the correlative relationship between the kinds of multiple intelligence common among them and their Grade Point Average (GPA).In particular, the current study aimed to answer the following main question:

((What are the kinds of Multiple Intelligence Common among College of Education Students at Dammam University and their Relationship with specialization, scholastic Year and Grade Point Average (GPA)?)). The study results indicated that there was no significance at the level of $(\alpha=0.05)$ responses of female students at the College of Education/ University of Dammam in musical intelligence and mathematical logical intelligence on the survey list of multiple intelligence that can be ascribed to university specialization variable. Meanwhile, there was significance at the level of $(\alpha=0.05)$ insignificant differences between the means of responses of female students at the College of Education/ University of Dammam on the survey list of multiple intelligence that can be ascribed to interaction between the two variables of university specialization and scholastic year, except for having a trace of interaction between the two variables of university specialization and scholastic year in the field of linguistic intelligence. The results of detecting the correlative relationship among the kinds of intelligence common among students of the College of 
Education at the University of Dammam and between their GPA indicated that the relationship between musical intelligence and GPA is negative but not significant. The results indicated an acceptable percentage of the kinds of multiple intelligence common among the students of the college of Education at Jubail/University of Dammam regarding the communality of the kinds of multiple intelligence among them indicating that intrapersonal intelligence was the most popular, while musical intelligence was the least popular. The ratio of mathematical - logical intelligence, visual intelligence, linguistic intelligence, interpersonal (social) intelligence, and bodilykinesthetic communality was approximate. The researcher justifies such ratio to the fertility rarity of enriching remedial study environment at which students live in their schools in general for all university specializations, specially students of the first year ( preparatory) in its two levels who are still influenced by the school environment, since they are still in the first stages of their university life. This agrees with the study conducted by (Christon \& Kennedy, 1999; Baldes et al., 2000; Janes et al., 2000) which indicated a positive impact of teaching employing multiple intelligence in teaching on students' motivation to learn. Each of these students came to the university with their school experience that formed the greatest part of their personality in general, and the kind of their intelligence in particular. Students of the $2^{\text {nd }}$, $3^{\text {rd }}$ and $4^{\text {th }}$ years do not go further than such environment although they get involved in the university life for two years according to the $2^{\text {nd }}$ year, three years according to the $3^{\text {rd }}$ year, and four years according to the $4^{\text {th }}$ year. This indicates the halo effect of school experience on the communality of multiple intelligence among them, and that such school environment has extended with its rare fertility - because of the teaching methods employed in schools, and because of other reasons including ignoring the learning styles preferred by students, which has the greatest influence of the communality of certain and multiple kinds of intelligence among them. To the university environment that looks through statistics barely the same, regarding the fertility of the teaching situation and the university teaching techniques (most often) as school life theoretically and practically in most of the university aspects and activities. The reason for that can be referred to the theoretical and practical materials in the university plan, which prepares students academically (specialization courses) and professionally (Curricular and Teaching Methodology courses and Psychology courses), for the various specializations. This agrees with the study conducted by Ozdener \& Ozcoban (2004) with the aim of comparing traditional learning methods, with a learning model based on multiple intelligence of having significant differences for the benefit of the learning method based on multiple intelligence. This also agrees with the study conducted by (Christon \& Kennedy, 1999) where results showed that students in the experimental 
group had a better understanding with higher learning performance and a rise in their motivation towards learning and used the learning styles that agree with their kind of intelligence. Since each society has its own particularity, the Saudi society has its own religious particularity which leaves its traces on its individuals at home, school and university. The less common kinds of intelligence among female students was musical intelligence being at the last place. Results indicated having apparent differences in the means of the responses of students to the list of multiple intelligence survey list in the light of the university specialization variable in each of the seven kinds of intelligence and all kinds of intelligence collectively. There were significant differences among the means of the responses of the students of the College of Education at Jubail/the University of Dammam in the musical intelligence and the mathematical- logical intelligence to the list of multiple intelligence survey that can be ascribed to the university specialization variable. As for musical intelligence, this result agrees with the results of the main question in the part concerned with the kinds of common multiple intelligence where musical intelligence was the least popular which is ascribed to the nature of the Saudi society and its religious beliefs. As for mathematical - logical intelligence, more than half of the students of the College of Education are from the literary stream. In this stream, students are not required to study mathematics at the secondary stages of the $1^{\text {st }}$ and $2^{\text {nd }}$ secondary grades, as a result of applying a policy that has nearly become a belief among the officials working in public and private sectors, represented by the Ministry of Education, that literary stream students do not have to study mathematics at schools. This led to students' indifference towards mathematics at the classes preceding the secondary classes, supposing that they would join the literary stream which is considered a way to get rid of mathematics. The Ministry of Education ignores the fact that university life has various courses that are considered a requirement for specialization, and that students have to pass them. For example, Educational Statistics which is taught to the students of the preparatory year, both scientific and literary, and literary stream students have to pass that course. Students keep away from mathematics in the last two years of their school life, without caring about mathematics in the previous years, because they would join the literary stream. In addition, literary stream female students have to stick to the specialization conditions after completing the $1^{\text {st }}$ year, which obliges literary stream students to take literary specializations such as English, Special Education and Kindergarten. This gave rise to such significance in the result of the mathematical - logical intelligence for the students in the literary university specializations in the $2^{\text {nd }}, 3^{\text {rd }}$ and $4^{\text {th }}$ years, and for the literary stream at the preparatory year. As for the scientific stream, in the preparatory year and the scientific specializations such as Mathematics, Physics and 
Computer Science- according to the university classification of such specializations, they are not luckier than the literary stream students regarding the statistical significance of their mathematical-logical intelligence, although it was for their advantage. This is ascribed, according to the researcher's point of view, to the theoretical and practical learning environment- as we mentioned in the discussion of the main question- which the university students are subject to after joining the specialization. Meanwhile, results indicate that there are no significant differences among the means of the response of the students of the Faculty of Education/University of Dammam to the remaining kinds of intelligence provided in the list of multiple intelligence survey. The sources of detecting the differences indicated having a statistical significance for the university specialization variable the response of the students of the Faculty of Education/university of Dammam to musical intelligence and mathematicallogical intelligence. Results indicated that the source of significant differences among the response of the students of the Faculty of Education/university of Dammam to musical intelligence, was between the responses of the preparatory scientific students on the one hand, and the responses of Kindergarten specialization students on the other hand for the benefit of the students of preparatory /scientific stream. The differences were also significant between the responses of the computer science students on the one hand, and the responses of preparatory/ literary, mathematics and Kindergarten students on the other hand for the benefit of the students of computer science, since that specialization is excluded to the scientific stream students. In addition to the fact that the highest average for admission and specialization is reserved for computer science, the differences were also significant between the responses of English students on the one hand, and the responses of mathematics and Kindergarten students on the other hand for the benefit of the students of English. This result indicates the communality of musical intelligence among the students of preparatory/ scientific to a greater degree, than their colleagues in the Kindergarten specializations from the literary stream. Musical intelligence is also popular among computer science students to a greater degree than their colleagues in the preparatory/ literary, Mathematics and Kindergarten specialization. Musical intelligence is also popular among English students to a greater degree than their colleagues in Mathematics and Kindergarten specialization are. The results also indicated that the source of significant differences among the response of the students of the Faculty of Education/university of Dammam to musical intelligence, were between the responses of the preparatory scientific students on the one hand, and the responses of Physics, English and Kindergarten students from the other hand for the benefit of the students of preparatory /scientific. This is ascribed to the nature of the 
scientific stream. There were also significant differences among the response of the students of Mathematics on the one hand and the responses of Physics, English and Kindergarten students from the other hand for the benefit of the students of Mathematics. This is ascribed to the fact that students specializing in Mathematics came from the scientific stream, in addition to the nature of Mathematic specialization at the university stage. This agrees with (Smith et al., 2000) about the impact of using multiple intelligence theory on the academic achievement of students in Mathematics. The study showed that multiple intelligence theory was not effective in metacognitive activities. This also agrees with (Yang \& Wu, 2001) that applied multiple intelligence theory on Mathematics syllabus for the students of two classes at a secondary school in Taiwan. The results showed that the performance of the first group in Mathematics was better than the performance of the control group, and that students' self-competency at some kinds of intelligence had increased, and that students' understanding of Mathematics, motivation, success and enjoying the material had increased. The differences were significant among the response of the students of Computer science on the one hand and the responses of preparatory/ literary, Physics, English and Kindergarten students from the other hand for the benefit of the students of computer science students. This result indicates the communality of mathematical-logical intelligence among the preparatory/scientific, Mathematics and Computer Science - this is ascribed to the reasons that we had mentioned before concerning the scientific stream and the scientific university specializations- to a greater degree from their colleagues in Physics, English, and Kindergarten, since such specializations are literary except for physics specialization, which is a difficult specialization and so a very small number of students join it. This supports the justification of the nature of the fertility or infertility of the learning environment and practices employed in it. This agrees with the study of (Awad, 2009; Ozdener \& Ozcoban, 2004; Janes et.al. 2000) on the positive effect of multiple intelligence in improving students' achievement and acquiring the basic scientific skills. This agrees with the study conducted by Baldes et al., 2000).The study results indicated that the program has reduced undisciplined behaviors and increased students' motivation towards achievement. The difference in the kinds of multiple intelligence common among the students of the College of Education in the light of scholastic year variable was detected. The means and standard deviations of students' responses to the multiple intelligence survey were produced, according to the scholastic year ( $1^{\text {st }}, 2$ nd, 3rd, and 4th) variable. Apparent differences were observed to the statistical significance of the differences in the means of students' responses to the multiple intelligence survey according to the scholastic year variable in each of the seven kinds of intelligence and all kinds of intelligence 
collectively. Results have shown having significant differences among the means of the response of the students of the College of Education at the University of Dammam in musical intelligence at the multiple intelligence survey that are ascribed to the scholastic year variable. Meanwhile the results in the same table indicate having no significant differences among the means of the response of the students of the College of Education at the University of Dammam in remaining types of intelligence at the multiple intelligence survey. This significance illustrates what we have mentioned before of the Saudi Arabia environment in which students live. Nevertheless, students living with individuals of diverse backgrounds - although they are of the same Saudi society- has led to making great effects among the kinds of multiple intelligence they have for the benefit of musical intelligence since the College of Education at Jubial has students from various cultures and diverse environment. In addition, the teaching faculty has come from societies other than the Saudi Arabian society who, through their teaching methods and ways of dealing with students, have a great impact on such students, in addition to the teaching faculty of Saudi nationality, but they are from diverse cultures. They have also graduated from foreign and Arabic universities, and so they acquired kinds of multiple intelligence from the learning styles that were practiced on them. The study believed that such influence was directly or indirectly transferred to such students, leading to such difference in intelligence for the benefit of musical intelligence. It seems that the study would like to notify that a change may occur in the quality of kinds of multiple intelligence common among students according to such variables and factors. This agrees with the study conducted by Janes et al., (2000) who observed that two kinds of multiple intelligence were successfully used to increase students' achievement and motivation. This was emphasized by the detection of the source of significant differences of having significance of the scholastic year variable among the response of the students of the Faculty of Education/university of Dammam to musical intelligence. Post comparison showed that the source of significant differences in the responses of the students of the College of Education at the University of Dammam towards musical intelligence was between the responses of the $4^{\text {th }}$ year students on the one hand and the responses of the $1^{\text {st }}$, 2nd and $3^{\text {rd }}$ year students on the other hand for the benefit of the students of $1^{\text {st }}, 2^{\text {nd }}$ and $3^{\text {rd }}$ students. This result indicates that the communality of musical intelligence is less among the $4^{\text {th }}$ year students, compared with their colleagues in the remaining scholastic years. The effect of interaction in the kinds of multiple intelligence common among the students of the College of Education at the University of Dammam in the light of scholastic year variable was detected. The means and standard deviations of students' responses to the multiple intelligence survey were produced according to the 
two variables of specialization (Mathematics, Physics, English, Computer Science and Kindergarten) and the scholastic year $\left(2^{\text {nd }}, 3^{\text {rd }}, 4^{\text {th }}\right)$. The $1^{\text {st }}$ year students were excluded because they have not specialized yet. The results indicated having no significant differences among the means and standard deviation of the responses of the students of the College of Education at the University of Dammam at the multiple intelligence survey that can be ascribed to the two variables of specialization and the scholastic year, except having impact of interaction between the two variables of specialization and the scholastic year in linguistic intelligence, which clearly increased among the $2^{\text {nd }}$ year students of English specialization compared with their colleagues at the $4^{\text {th }}$ year. Meanwhile, linguistic intelligence clearly increased among the $3^{\text {rd }}$ year students of Kindergarten specialization compared with their colleagues at the $4^{\text {th }}$ year. The results of the correlation relation between the kinds of intelligence common among students of the College of Education at Dammam University and their GPA indicated that the relation between the musical intelligence and GPA was negative but insignificant. Meanwhile, the remaining kinds of intelligence had a positive relation although it was a simple relation with GPA. Results indicated that there is a positive relationship between mathematical-logical intelligence and linguistic intelligence and the seven kinds of intelligence collectively and the university GPA is simple and significant. This agrees with the studies conducted by Awad, 2009; Ozdener \& Ozcoban, 2004; Janes et al., 2000) on the positive effect of multiple intelligence in improving students' achievement and acquiring the basic scientific skills. This result indicates having a simple, positive and significant relation between mathematicallogical intelligence and linguistic intelligence and the seven kinds of intelligence in general and the university GPA, and that the best correlative relationship was between the mathematical-logical intelligence of intelligence and the university GPA.

\section{References:}

1. Jabber, Abdul-Hamid, . Multiple Intelligence and Understanding: Development and deepening, Cairo, Dar El-Fikr Al-Arabi.(2003).

2. Al-Sorour, Nadia, 0 Introduction to Educating the Excellent and the Gifted, Amman, Dar El-Fikr for Publishing. (1998).

3. Zaitoun, Iman Moh'd Ali . "The Effect of a Teaching Program Based on Integrating Multiple Intelligence and Learning Styles on Students' Ability to Solve Mathematical Problems and on Increasing their Motivation to Learn Mathematics”, A PhD Thesis, University of Jordan, Amman, Jordan. (2010)

4. Awad, Amal. The effect of a Teaching Strategy Based on the Multiple Intelligence Theory on Understanding Physics 
Concepts, Scientific Attitudes and Ability to Solve Problems among Primary Stage Students, Unpublished $\mathrm{PhD}$ Thesis, University of Jordan, Amman, Jordan. (2009).

5. Afaneh, Izzo \& Khazendar, Naela, . Teaching Classrooms by Multiple Intelligence, Amman, Dar- Al-Masirah. (2007).

6. The Ministry of Education,. Remedial Activities Guide of Learning Styles, Examination Section, Directory of Examination, Amman, Jordan. (2005).

7. Wahibi, Ahmad Atef, . The Relationship Between Multiple Intelligence and Locus of Control among the University of Jordan Students on the one hand and their motivation towards achievement on the other hand, Unpublished PhD Thesis, Amman Arab University for Graduate Studies, Amman, Jordan. (2004).

8. Foreign References:

9. Ahmadyan, Hamze. The Effect of Teaching Strategy Based on Multiple Intelligences on Students' Academic Achievement in Science Course. Universal Journal of Educational Research 1(4): 281-284, $2013 \quad$ http://www.hrpub.org DOI: 10.13189/ujer.2013.010401. (2013).

10. Christison, M.A. \& Kennedy, D.. Multiple Intelligences: Theory and Practice in AdultESL. Key Resources. Retrieved from http://www.cal.org/adultesl/resources/digests/multipleintelligences.php.(1999).

11. Gardner, Howard.. Multiple Intelligences: The Theory in Practice, New York: Basic Books. (1993).

12. Gardner, Howard. Audiences for the Theory of Multiple Intelligences. Teachers College Record, 106(1), 212-220. (2004).

13. Janes, L. M. Koutsopanagos, C. L. Mason, D. S. and Villaranda I.. Improving Student Motivation through the Use of, Engaged Learning, Cooperative Learning and Multiple Intelligences, Master's Action Research Project, Saint Xavier University and Skylight Professional Development Field -Based Master's Program, ED443559. (2000).

14. Ozdener, N., \& Ozcoban, T.. A project based learning model's effectiveness on computer courses and multiple intelligence theory. Educational Sciences: Theory and Practice. 4, 176-180. (2004).

15. McKenzie, W.. Multiple Intelligence inventory. Retrieved April 4, 2005 from: http://surfaquarium.com $\backslash$ MIlinventory,htm.(1999)

16. Rogalla, M. and Margison, J.. Future Problem Solving Program Coaches Efficacy in Teaching For Successful Intelligence and 
Their Patterns Of Successful Behavior, Roeper Review, 26 (3): 175 - 177. (2004).

17. Silver, H. Strong, R. and Perini, M.. Integrating Learning Styles and Multiple Intelligences, Educational Leadership 27-22: (1) 55. (1997).

18. Smith, D., Letourneau, E. J., Saunders, B. E., Kilpatrick, D. G., Resnick, H. S., \& Best, C. L.. Delay in disclosure of childhood rape: Results from a national survey. Child Abuse \& Neglect, 24, 273-287. (2000). 